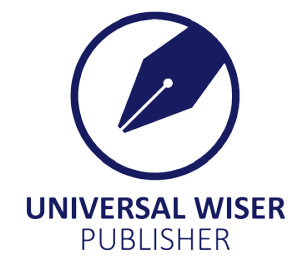

\title{
Evaluation of Growth Kinetics and Biomass Yield of Baker's Yeast on Potato Flour
}

\author{
Md. Kowser Ali, Maria Afroz Toma ", Radhia Sultana, Mohammad Gulzarul Aziz \\ Department of Food Technology and Rural Industries, Faculty of Agricultural Engineering and Technology, Bangladesh Agricultural \\ University, Mymensingh-2202 \\ Email: matomaftri@bau.edu.bd
}

\begin{abstract}
The study aims to evaluate the growth kinetics of two different Baker's yeast (S. cerevisiae) strains and to establish regression models for predicting and optimizing of the growth conditions of the strains. Two yeast strains of S. cerevisiae; one was commercial strain (CS) and another was isolated from traditional dry wine residue of Madhupur region, Bangladesh (MS), were used in the study. The effects of four different factors viz., time, temperature, agitation and the potato powder concentrations were assessed. The performance of the growth of the strains was monitored using three responses like OD at $600 \mathrm{~nm}$, ethanol production and biomass yield $\left(\mathrm{g} . \mathrm{L}^{-1}\right)$. Fractional factorial design $\left(2^{4-1}\right)$ was used to generate the experimental trials as well as to analyze the data to design a geometrical representation. The highest value of optical density, ethanol and biomass production for S. cerevisiae (CS) were obtained 1.439, $6.56\left(\mathrm{~g} . \mathrm{L}^{-1}\right)$ and 0.39 (g.L $\mathrm{L}^{-1}$ ) respectively, and for S. cerevisiae (MS) were $0.645,0.621\left(\mathrm{~g} . \mathrm{L}^{-1}\right)$ and $0.23\left(\mathrm{~g} . \mathrm{L}^{-1}\right)$, respectively. The best conditions for biomass production were at $1 \%$ of potato powder concentration, temperature at $30^{\circ} \mathrm{C}$ and agitation at $150 \mathrm{rpm}$. By using regression model it can be said that for two factor interaction: potato powder concentration with time and time with agitation had the significant effects but three factor interactions had no significant effect on the experiment. By establishing regression models from the obtained data, prediction and optimization of the strains' growth conditions can be easily done. Keywords: potato flour, Baker's yeast, biomass and ethanol production, factorial design
\end{abstract}

\section{Introduction}

S. cerevisiae (Baker's yeast) is widely known for its ethanol and biomass production in a broad context of fermentation because it is less susceptible to infection than any other microbes like bacteria. Furthermore, its ability to tolerate ethanol is also quite better than other ethanol producing microbes ${ }^{[1]}$. Among all of the microorganisms, Saccharomyces cerevisiae is generally taken into consideration for its advantageous utilization as safe for human consumption. In a wide range of bread production, $S$. cerevisiae is used in the leavening of dough because it can produce ethanol and carbon dioxide by utilizing the sugar present in the dough ${ }^{[2]}$. Both active and instant dry yeast can be produced from Saccharomyces cerevisiae ${ }^{[3]}$.

The substrates recommended for biomass and ethanol production should be efficient and cheap containing a high percentage of carbon source such as molasses $\mathrm{B}^{[4]}$, sugar beet pul $\mathrm{p}^{[5]}$, sugarcane ${ }^{[6]}$, waste produced during starch production from cassava ${ }^{[7]}$, food waste ${ }^{[8]}$, and waste newspapers ${ }^{[9]}$. These carbon sources are considered as high value products of food source ${ }^{[10]}$. Potato flour used in the study, is an ideal substrate for growth of Baker's yeast. $100 \mathrm{~g}$ potato flour contains about 91\% carbohydrate and 4\% minerals with a small amount of protein and fat. Potato can be an alternative source for both biomass production of S. cerevisiae ${ }^{[11]}$ and ethanol production because of its high percentage of carbon. For commercial production of yeast, potato flour is a good source of carbon because of its low cost and availability throughout the country. But in Bangladesh, most of the baking industries use baking powder as it is less expensive than bakers' yeast and also our country doesn't produce it. That's why it is being imported from foreign countries in a large amount every year for the baking purpose which makes it costly too ${ }^{[12]}$.

In an experiment, generally the number of trials rapidly increases with the number of factors. For reducing experiment trial numbers, times, and expenses, the fractional factorial design is very useful ${ }^{[13]}$. The use of fractional factorial design in the study can have a significant effect on statistical analysis to get a better result. This research employed fractional factorial design $2^{4-1}$ to investigate the influence of four parameters like time, temperature, agitation and substrate 
concentration on the laboratory scale yeast cell growth monitoring biomass yield at OD $600 \mathrm{~nm}$ and weighing dry yeast cells. Ethanol production was also monitored.

\section{Materials and methods}

\subsection{Collection and transportation of dry wine residue sample}

Dry wine residue (Figure 1) used to isolate Saccharomyces cerevisiae strains were collected from traditional dry wine residue of Madhupur upazila, Mymensingh collected using sterilized enclosed polythene bags with proper labeling. These samples were carried to the laboratory and kept in normal storage condition for microbiological studies.

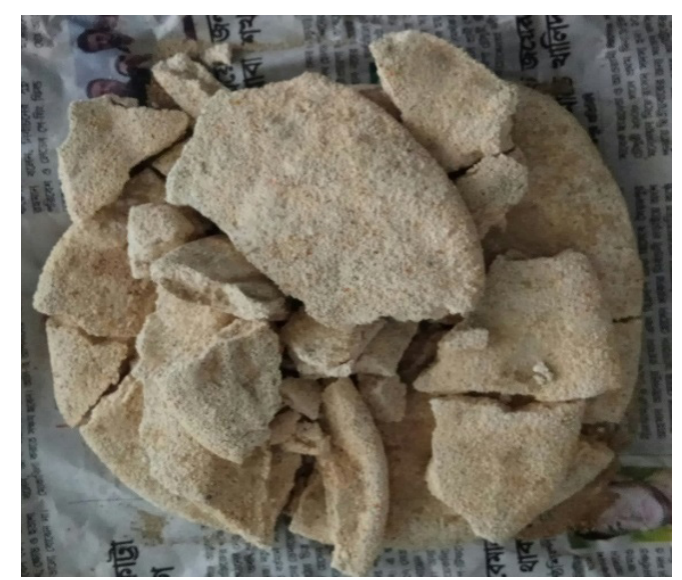

Figure 1. Collection of dry wine residue sample

\subsection{Isolation of strain from dry wine residue}

Isolation of yeast strain was done by using the serial dilution plate technique method. $1 \mathrm{~g}$ of the dry wine residue sample was taken in a $250 \mathrm{ml}$ Erlenmeyer flask containing $50 \mathrm{ml}$ sterilized water. The flasks were shaken using a rotary shaker for 10 min tear of the spores from the solution. Then the suspended matter was allowed to settle down and the suspension was serially diluted up to $10^{-6}$ times.

\subsection{Inoculation and incubation of the samples}

Spread plate technique was used throughout this study. $1 \mathrm{ml}$ of diluted samples prepared from wine residue was transferred on MEAB plates using sterile pipette and spreaded with the help of sterile glass rod. All of the MEAB plates were then incubated in an incubator at $30 \pm 2^{\circ} \mathrm{C}$ for 48 hours. Inoculum prepared from yeast samples was streaked onto MEA medium and incubated at $37^{\circ} \mathrm{C}$ for 24 hours. After incubation the colony morphology and color were recorded to identify the Saccharomyces spp. Colony of Saccharomyces were sub-cultured onto MEA. A small lump of yeast mycelia was picked up by sterile tooth prick and directly placed on MEA and incubated at $37^{\circ} \mathrm{C}$ for 24 hours to get pure cultures.

\subsection{Sub-merge cultivation of Sacharomyces cerevisiae}

For sub-merge cultivation of Saccharomyces cerevisiae, potato flour solution was used. For the preparation of potato flour solution, $3 \mathrm{~g}$ and $5 \mathrm{~g}$ flour was dissolved in $100 \mathrm{ml}(3 \%)$ and $500 \mathrm{ml}(1 \%)$ distilled water respectively. The media was then sterilized by autoclaving at $121^{\circ} \mathrm{C}$ and $15 \mathrm{psi}$ for $15 \mathrm{~min}$. The medium was sterilized by incubating overnight at $37^{\circ} \mathrm{C}$. The incubated medium was used to evaluate cultural characterization of the strain or stored at $4^{\circ} \mathrm{C}$ for future use. Inoculation of inoculum on potato flour media was done at $30^{\circ} \mathrm{C}$ and $40^{\circ} \mathrm{C}$, at 100 and $150 \mathrm{rpm}$ for 25 and 50 hours ${ }^{[14]}$.

\subsection{Proximate analysis of potato flour}

The proximate composition of potato flour was analysed for moisture, crude protein, crude fat, and ash content as per the methods of [15]. The total carbohydrate content of the sample was calculated by subtracting the measured crude protein, crude fat, ash and moisture content from $100^{[16]}$.

\section{Study design}

The influence of four factors at two different levels on the optical density, alcohol and biomass production during growth of Saccharomyces cerevisiae was assessed. The design matrix is given in Table 1. 
Table 1. Design matrix

\begin{tabular}{ccccc}
\hline \multirow{2}{*}{ Label } & \multirow{2}{*}{ Factors } & \multicolumn{3}{c}{ Levels } \\
\cline { 3 - 5 } & & -1 & Central \\
\hline $\mathrm{A}$ & Potato powder concentration (\%) & 1 & 2 & 3 \\
$\mathrm{~B}$ & Time (min) & 25 & 37.5 & 50 \\
$\mathrm{C}$ & Temperature $\left({ }^{0} \mathrm{C}\right)$ & 30 & 35 & 40 \\
$\mathrm{D}$ & Agitation $(\mathrm{rpm})$ & 100 & 125 & 150 \\
\hline
\end{tabular}

Total trials for the above design matrix (Table 1) were including three trials at the central point. Table 2 indicates total trials with their coded value.

Table 2. Total trial with coded value

\begin{tabular}{|c|c|c|c|c|}
\hline \multirow{2}{*}{ Trial } & \multicolumn{4}{|c|}{ Factor levels } \\
\hline & A & B & $\mathrm{C}$ & D \\
\hline 1 & -1 & -1 & -1 & -1 \\
\hline 2 & +1 & -1 & -1 & +1 \\
\hline 3 & -1 & +1 & -1 & +1 \\
\hline 4 & +1 & +1 & -1 & -1 \\
\hline 5 & -1 & -1 & +1 & +1 \\
\hline 6 & +1 & -1 & +1 & -1 \\
\hline 7 & -1 & +1 & +1 & -1 \\
\hline 8 & +1 & +1 & +1 & +1 \\
\hline 9 & 0 & 0 & 0 & 0 \\
\hline
\end{tabular}

It was employed that the $2^{4-1}$ design defining the relation $\mathrm{I}=\mathrm{ABCD}$, where $\mathrm{I}$ is the identity column. Because of that choice of generator will result highest possible resolution (IV) in the design. Each main effect was evaluated with another three-factor interaction: $\mathrm{A}=\mathrm{BCD}, \mathrm{B}=\mathrm{ACD}, \mathrm{C}=\mathrm{ABD}$ and $\mathrm{D}=\mathrm{ABC}$. Also every two-factor interaction was analyzed with another two-factor interaction and that was $\mathrm{AB}=\mathrm{CD}, \mathrm{AC}=\mathrm{BD}$ and $\mathrm{DA}=\mathrm{BC}$. All experiments were made in triplicate to estimate the experimental errors, and another experiment was carried out in triplicate at the central point. Furthermore, all 54 experiments were done in the study. The ranges were chosen for factors such as potato powder concentration (A), time (B), temperature (C) and agitation (D) were $1 \%-3 \%, 25$ hours-50 hours, $30^{\circ} \mathrm{C}-40^{\circ} \mathrm{C}$ and $100 \mathrm{rpm}-150 \mathrm{rpm}$, respectively. Following the usual convention, the two extreme levels are denoted by minus one (lower level) and plus one (higher level). This leads to a convenient algorithm to analyze the experimental results. The studied dependent variables were: optical density, ethanol production (\%) and biomass production $\left(\mathrm{g} \cdot \mathrm{L}^{-1}\right)$.

\subsection{Measurement of ethanol production}

The amount of ethanol was measured in a glass tube containing a scale calibrated with the reading on its level. The surface of the liquid in which the hydrometer is floating indicates the number of times heavier or lighter than water, i.e., the specific gravity of the liquid. The hydrometer was based on Archimedes principle. The formula for converting specific gravity to alcohol was [17],

$$
\mathrm{ABV}=(\mathrm{OG}-\mathrm{FG}) * 131.25
$$

Where $\mathrm{OG}=$ original gravity and $\mathrm{FG}=$ final gravity.

\subsection{Measurement of optical density by spectrophotometer}

The yeast cell in the broth is directly proportional to the absorbance at $600 \mathrm{~nm}$. Based on this principle, yeast cell growth was monitored by measuring optical density of the yeast broth using a spectrophotometer at 600 nm wavelength ${ }^{[18]}$.

\subsection{Measurement of cell growth by dry cell weight methods}

Dry cell weight was measured by oven drying method as described by Reis ${ }^{[19]}$ with slight modification. In this method, about $10 \mathrm{~mL}$ broth was taken in a pre-weighed centrifuge tube $\left(\mathrm{w}_{1}\right)$ and centrifuged at $6000 \mathrm{rpm}$. After centrifugation of the cell broth, the supernatant was discarded and the filtrated remained in the tube was placed in an air oven for drying at $65^{\circ} \mathrm{C}$ for 1 hour. After drying, weight $\left(\mathrm{W}_{2}\right)$ was taken. Then the biomass yield or dry weight was measured by using the formula, 


$$
\operatorname{Dry} w t\left(\frac{g}{L}\right)=\frac{w_{2}-w_{1}}{5} \times 1000
$$

\section{Statistical analysis}

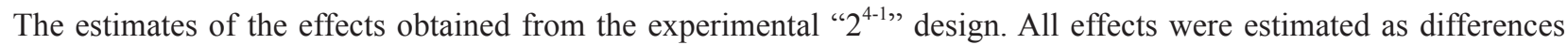
between two averages and each average containing half of the experimental responses. The intermediate trials were ignored at that stage, and used only to investigate possible curvatures. The interaction effects are linear combinations of the form $^{[13]}$,

$$
\frac{1}{4} \sum_{i}^{n} \text { aiyi }
$$

Where, $y_{i}$ was the average response in trial $i$ and the coefficient $a_{i}$ was set equal to plus or minus one, depending on the sign of the product of the columns of the factors involved. The calculations were done using statistica (version 5.1) and MATLAB (version 4.2 c.1) software's.

\section{Results and discussion}

\subsection{Proximate analysis of potato flour}

Potatoes can be an appropriate alternate substrate for biomass yield and bioethanol production due to their plenty of availability, low cost, and easy processing. The major part of potato was carbohydrate as starch followed by ash. The dominancy of carbohydrate constituents of potato flour was also revealed from its analysis on the basis of dry basis. From the proximate analysis of potato flour it was found that the amount of carbohydrates was $90.71 \%$ which were similar to the findings of [20] who observed $90.6 \%$ carbohydrate in potato flour. The fat content was found $0.99 \%$ which was closed to the findings $(1.02 \%)$ as reported by [21]. Boni et al. ${ }^{[22]}$ reported the similar percentages of moisture, protein and ash content in the potato flour with that of found in this study. The nutritional composition of $100 \mathrm{~g}$ potato flour is shown in Table 3 .

Table 3. Proximate analysis of potato flour

\begin{tabular}{ccc}
\hline Components & Content $(\%)(w b)$ & Content $(\%)(\mathrm{db})$ \\
\hline Protein & $0.90 \pm 0.07$ & $0.93 \pm 0.03$ \\
Fat & $0.96 \pm 0.05$ & $0.99 \pm 0.06$ \\
Carbohydrates & $90.71 \pm 0.13$ & $93.91 \pm 0.19$ \\
Ash & $4.02 \pm 0.02$ & $4.16 \pm 0.09$ \\
Moisture & $3.41 \pm 0.07$ & $3.53 \pm 0.08$ \\
\hline
\end{tabular}

\subsection{Effect of experimental condition on the growth of yeast}

Effects of time, temperature and agitation on the growth and biomass yield of S. cerevisiae of both CS and MS. These parameters were also observed for their effect on ethanol production and optical density measurement of cell growth. The inoculated yeast with potato flour solution was incubated at $30^{\circ} \mathrm{C}$ and $40^{\circ} \mathrm{C}$ at 100 and $150 \mathrm{rpm}$ for 25 hours and 50 hours according to the experimental design. The obtained results for Optical Density (OD), $\%$ alcohol and dry weight were given in Table 4. The experimental factors like temperature range and $\mathrm{pH}$ were selected based on a performance study carried out with unhydrolyzed potato waste to produce ethanol using $S$. cerevisiae at a temperature range of $20^{\circ} \mathrm{C}$ to $50^{\circ} \mathrm{C}$ and at $\mathrm{pH}$ range of 4 to 7 for 7 days and the optimum $\mathrm{pH}$ and temperature for the fermentation of waste potatoes was reported to be 6 and $30^{\circ} \mathrm{C}$, respectively ${ }^{[23]}$. Based on this study, experimental factors were selected as temperature ranged between $30^{\circ} \mathrm{C}$ and $40^{\circ} \mathrm{C}$, speed 100 and $150 \mathrm{rpm}$ and time ranged between 25 hours and 50 hours to the experimental design.

\subsection{Biomass production}

In the study, all S. cerevisiae strain showed better biomass production about two to three fold in shaking at $150 \mathrm{rpm}$ than $100 \mathrm{rpm}$ culture ${ }^{[24]}$. From the observation of biomass production of Saccharomyces cerevisiae (CS), the highest yield was 0.39 g.L. $\mathrm{L}^{-1}$ and $0.23 \mathrm{~g}$ g. $\mathrm{L}^{-1}$ (Table 4) for Saccharomyces cerevisiae MS which corresponded to the experiment at trial of number 3 for both of the strains. The conditions of trial no. 3 were $1 \%$ potato powder concentration for 50 hours' at $30^{\circ} \mathrm{C}$ and at speed of $150 \mathrm{rpm}$. 


\subsection{Ethanol production}

Considering ethanol as the final product of fermentation, the best production of alcohol was observed as $0.656 \%$ (6.566 $\left.\mathrm{g} / \mathrm{L}^{-1}\right)$ for S. cerevisiae CS and $0.621 \%\left(6.21 \mathrm{~g} / \mathrm{L}^{-1}\right)$ (Table 4) for Saccharomyces cerevisiae MS which corresponded to the experiment trial number 8 for both of the strains. The conditions of trial no. 8 were $3 \%$ potato powder concentration for 50 hours' time at $40^{\circ} \mathrm{C}$ temperature and agitation at $150 \mathrm{rpm}$. The maximum ethanol production was $27.7 \mathrm{~g} / \mathrm{L}$ obtained at controlled $\mathrm{pH}$ and inoculum size as $3 \%^{[25]}$. Temperature between $25-30^{\circ} \mathrm{C}$ was commonly found optimum for thermophilic $S$. cerevisiae strain for ethanol production in various substrates such as apple pomace, sweet sorghum, etc. ${ }^{[26]}$.

\subsection{Optical density}

Both Saccharomyces cerevisiae CS and MS showed higher optical density than others at trial number 3 . The conditions of trial no. 3 were $1 \%$ potato powder concentration for 50 hours time at $30^{\circ} \mathrm{C}$ temperature and agitation at 150 $\mathrm{rpm}$. Commercial yeast showed higher optical density 1.439 at $1 \%$ potato powder concentration for 50 hours at $30^{\circ} \mathrm{C}$ and at a speed of $150 \mathrm{rpm}$. MS yeast showed higher optical density 0.645 also at $1 \%$ potato powder concentration for 50 hours at $30^{\circ} \mathrm{C}$ and a speed of $150 \mathrm{rpm}$ (Table 4). In the study, it was found that the best output obtained at $30^{\circ} \mathrm{C}$. For maximum growth and ethanol production, $30^{\circ} \mathrm{C}$ was the most appropriate temperature for $S$. cerevisiae y-1646 was reported by scientists. At $30^{\circ} \mathrm{C}$ temperature, biomass was estimated as $2.47(\mathrm{OD} 500 \mathrm{~nm})$ but the production of ethanol by S. cerevisiae $\mathrm{y}-1646$ was favored by temperature of $35^{\circ} \mathrm{C}$ and reached its maximum $\left(5.29 \mathrm{~g} \mathrm{~L}^{-1}\right)$ after $36 \mathrm{~h}^{[14]}$.

\begin{tabular}{|c|c|c|c|c|c|c|c|c|c|}
\hline $\begin{array}{l}\text { Potato } \\
\text { powder } \\
\text { conc. }(\%)\end{array}$ & $\begin{array}{l}\text { Time } \\
(\mathrm{min})\end{array}$ & $\begin{array}{c}\text { Temp. } \\
\left({ }^{0} \mathrm{C}\right)\end{array}$ & $\begin{array}{l}\text { Agitation } \\
\text { (rpm) }\end{array}$ & $\begin{array}{c}\text { Optical Density } \\
\text { (OD) } \\
\text { CS }\end{array}$ & $\begin{array}{c}\text { Optical Density } \\
\text { (OD) } \\
\text { MS }\end{array}$ & $\begin{array}{c}\text { \% ethanol } \\
\text { CS }\end{array}$ & $\begin{array}{c}\text { \% ethanol } \\
\text { MS }\end{array}$ & $\begin{array}{c}\text { Dry wt. } \\
\left(\text { g.L }{ }^{-1}\right) \\
\text { CS }\end{array}$ & $\begin{array}{c}\text { Dry wt. } \\
\left(\text { g.L } L^{-1}\right) \\
\text { MS }\end{array}$ \\
\hline 1 & 25 & 30 & 100 & 0.927 & 0.309 & 0.196 & 0.131 & 0.16 & 0.130 \\
\hline 3 & 25 & 30 & 150 & 1.209 & 0.209 & 0.393 & 0.135 & 0.22 & 0.090 \\
\hline 1 & 50 & 30 & 150 & 1.439 & 0.645 & 0.315 & 0.433 & 0.39 & 0.230 \\
\hline 3 & 50 & 30 & 100 & 1.344 & 0.621 & 0.525 & 0.513 & 0.18 & 0.150 \\
\hline 1 & 25 & 40 & 150 & 1.014 & 0.242 & 0.262 & 0.196 & 0.19 & 0.120 \\
\hline 3 & 25 & 40 & 100 & 1.036 & 0.252 & 0.433 & 0.261 & 0.23 & 0.110 \\
\hline 1 & 50 & 40 & 100 & 1.135 & 0.381 & 0.371 & 0.315 & 0.21 & 0.14 \\
\hline 3 & 50 & 40 & 150 & 1.379 & 0.631 & 0.656 & 0.621 & 0.23 & 0.210 \\
\hline
\end{tabular}

\subsection{Average results for biomass, ethanol production and optical density}

Data in Table 5 showed the average results of the production of biomass, optical density and ethanol, using the experimental design from Table 1.

The estimates of the effects obtained from the $2^{4-1}$ design to get the main effects one thus refers to the responses in Table 6, the signs of the corresponding columns in Table 1, performs the algebraic sum, and divides the result by four.

To illustrate the calculations, the linear combination of observations associated with the effect A in optical density for Saccharomyces cerevisiae CS, changes is

$$
\mathrm{I}_{\mathrm{A}}=(1 / 4)[-(0.16)+(0.22)-(0.39)+(0.18)-(0.19)+(0.23)-(0.21)+(0.23)=0.0225] \rightarrow \mathrm{A}+\mathrm{BCD} \text {. }
$$

For Saccharomyces cerevisiae MS, changes is

$$
\mathrm{I}_{\mathrm{A}}=(1 / 4)[-(0.13)+(0.09)-(0.23)+(0.15)-(0.12)+(0.11)-(0.14)+(0.21)=-0.015] \rightarrow \mathrm{A}+\mathrm{BCD}
$$

The interaction effects are linear combinations of the form ${ }^{[13]}$.

$$
\frac{1}{4} \sum_{i}^{n} \text { aiyi }
$$

Where, $y_{i}$ was the average response in trial $i$ and the coefficient $a_{i}$ was set equal to plus or minus one, depending on the sign of the product of the columns of the factors involved. For example, to calculate the $A B(=C D)$ interaction for Saccharomyces cerevisiae CS,

$$
I_{A B}=(1 / 4)[+(0.16)-(0.22)-(0.39)+(0.18)+(0.19)-(0.23)-(0.21)+(0.23)=-0.0725 \rightarrow A B+C D \text {. }
$$


To calculate the $\mathrm{AB}(=\mathrm{CD})$ interaction Saccharomyces cerevisiae MS,

$\mathrm{I}_{\mathrm{AB}}=(1 / 4)[+(0.13)-(0.09)-(0.23)+(0.15)+(0.14)-(0.11)-(0.14)+(0.21)=0.01 \rightarrow \mathrm{AB}+\mathrm{CD}$.

Table 5. Average values of optical density, ethanol and biomass production followed by the conditions defined in Table 1

\begin{tabular}{|c|c|c|c|c|c|c|}
\hline Trial & $\begin{array}{l}\text { OD } \\
\text { CS }\end{array}$ & $\begin{array}{l}\text { OD } \\
\text { MS }\end{array}$ & $\begin{array}{c}\text { Ethanol (\%) } \\
\text { CS }\end{array}$ & $\begin{array}{c}\text { Ethanol (\%) } \\
\text { MS }\end{array}$ & $\begin{array}{c}\text { Biomass }(\mathrm{g} / \mathrm{L}) \\
\mathrm{CS}\end{array}$ & $\begin{array}{c}\text { Biomass }(\mathrm{g} / \mathrm{L}) \\
\mathrm{MS}\end{array}$ \\
\hline 1 & 0.927 & 0.309 & 0.196 & 0.131 & 0.160 & 0.130 \\
\hline 2 & 1.209 & 0.209 & 0.393 & 0.135 & 0.220 & 0.090 \\
\hline 3 & 1.439 & 0.645 & 0.315 & 0.433 & 0.390 & 0.230 \\
\hline 4 & 1.344 & 0.621 & 0.525 & 0.513 & 0.180 & 0.150 \\
\hline 5 & 1.014 & 0.242 & 0.262 & 0.196 & 0.190 & 0.120 \\
\hline 6 & 1.036 & 0.252 & 0.433 & 0.261 & 0.230 & 0.110 \\
\hline 7 & 1.135 & 0.381 & 0.371 & 0.315 & 0.210 & 0.14 \\
\hline 8 & 1.379 & 0.631 & 0.656 & 0.621 & 0.230 & 0.210 \\
\hline 9 & 1.365 & 0.550 & 0.359 & 0.453 & 0.206 & 0.130 \\
\hline
\end{tabular}

The average results for biomass production, optical density and ethanol were obtained by using $2^{4-1}$ design. From Table 6 and 7, for biomass production, it is reasonable to conclude that the main effects A, B and D had large values and $\mathrm{A}, \mathrm{B}$ and $\mathrm{D}$ were the most important effects, then it was logical to conclude that the interaction alias chain $\mathrm{AC}=\mathrm{BD}$ had a large effect because $\mathrm{BD}$ was also significant ${ }^{[27]}$.

Table 6. Estimates of effects, aliases for the design $2^{4-1}$ (Table 1) calculated based on the results presented in Table 2 (Saccharomyces cerevisiae CS and MS)

\begin{tabular}{|c|c|c|c|c|c|c|}
\hline Effects & $\begin{array}{c}\text { Estimated } \\
\text { (OD) } \\
\text { CS } \\
\end{array}$ & $\begin{array}{c}\text { Estimated } \\
\text { (OD) } \\
\text { MS } \\
\end{array}$ & $\begin{array}{c}\text { Estimated } \\
\text { Ethanol }(\%) \\
\text { CS }\end{array}$ & $\begin{array}{c}\text { Estimated } \\
\text { Ethanol (\%) } \\
\text { MS }\end{array}$ & $\begin{array}{l}\text { Estimated Biomass } \\
\text { production }(\mathrm{g} / \mathrm{L}) \\
\text { CS }\end{array}$ & $\begin{array}{l}\text { Estimated Biomass } \\
\text { production }(\mathrm{g} / \mathrm{L}) \\
\text { MS }\end{array}$ \\
\hline $\mathrm{I}_{\mathrm{A}} \rightarrow \mathrm{A}+\mathrm{BCD}$ & 0.113 & 0.034 & 0.216 & 0.114 & 0.023 & -0.015 \\
\hline $\mathrm{I}_{\mathrm{B}} \rightarrow \mathrm{B}+\mathrm{ACD}$ & 0.278 & 0.317 & 0.583 & 0.290 & 0.053 & 0.070 \\
\hline $\mathrm{I}_{\mathrm{C}} \rightarrow \mathrm{C}+\mathrm{ABD}$ & -0.089 & -0.070 & 0.073 & -0.045 & -0.023 & -0.005 \\
\hline $\mathrm{I}_{\mathrm{D}} \rightarrow \mathrm{D}+\mathrm{ABC}$ & 0.141 & 0.041 & 0.025 & 0.041 & 0.063 & 0.030 \\
\hline $\mathrm{I}_{\mathrm{AB}} \rightarrow \mathrm{AB}+\mathrm{CD}$ & -0.039 & 0.079 & 0.032 & 0.079 & -0.073 & 0.010 \\
\hline $\mathrm{I}_{\mathrm{AC}} \rightarrow \mathrm{AC}+\mathrm{BD}$ & 0.012 & 0.096 & 0.012 & 0.072 & 0.053 & 0.045 \\
\hline $\mathrm{I}_{\mathrm{AD}} \rightarrow \mathrm{AD}+\mathrm{BC}$ & -0.046 & -0.058 & 0.020 & -0.050 & -0.043 & -0.010 \\
\hline
\end{tabular}

Effects and interactions of theoretical $2^{4-1}$ in yeast growth

Effects of interactions of theoretical $2^{4-1}$ in yeast growth and biomass production of Saccharomyces cerevisiae for both strains are shown in Table 7. The principle effects of the experiment are potato powder concentration, time and agitation. Among them, time and agitation had a significant effect for both strains. For two factor interaction, potato powder concentration with time and time with agitation had a significant effect for Saccharomyces cerevisiae CS. For Saccharomyces cerevisiae MS, only time with agitation had a significant effect. Three factor interactions had no significant effect on the experiment.

Table 7. Results of principle effects and interactions of theoretical $2^{4-1}$ in yeast growth and biomass production

\begin{tabular}{ccc}
\hline & Estimated (S. cerevisiae CS) & Estimated (S. cerevisiae MS) \\
\hline Principal effects & & -0.015 \\
Potato powder concentration (A) & 0.023 & 0.07 \\
Time (B) & 0.053 & 0.03 \\
Agitation (D) & 0.063 & 0.01 \\
Two factor interaction: & & -0.01 \\
AB $\rightarrow$ & -0.073 & 0.045 \\
AD $\rightarrow$ & -0.043 & -0.005 \\
BD $\rightarrow$ & 0.053 & \\
Three factor interaction: & -0.023 & \\
ABD $\rightarrow$ &
\end{tabular}




\subsection{Geometrical representation of biomass production}

From inception of the information in Table 6, it was reasonable to conclude that the main effect B and D were the large and that the $\mathrm{I}_{\mathrm{AB}}$ and $\mathrm{I}_{\mathrm{AC}}$ were also significant. This agrees with the conclusion from the analysis of the complete $2^{4-1}$ design.

Since factor $\mathrm{A}$ and $\mathrm{C}$ were not significant, so we may drop them from consideration. Consequently we may project this $2^{4-1}$ design into a single replicate of the $2^{4-1}$ design in factors B and D (Figure 2 and Figure 3). Visual examination of this cube plot made us more comfortable with the conclusion reached above. It was noticed that if the time (B) and agitation (D) was at high level, the production of biomass had a large positive effect. And where the time and agitation at low level, the biomass production had a very small effect which was likely due to the BD interactions. Furthermore, if the time (B) was at high level, the concentration (A) was negligible.

Based on the above analysis, we obtained a model to predict biomass yield over the experimental region. The model was

$$
\mathrm{Y}=\beta_{0}+\beta_{2} \cdot \mathrm{X}_{2}+\beta_{4} \mathrm{X}_{4}+\beta_{12} \cdot \mathrm{X}_{1} \mathrm{X}_{2}+\beta_{13} . \mathrm{X}_{1} \mathrm{X}_{3}
$$

Where $\mathrm{X}_{1}, \mathrm{X}_{2}, \mathrm{X}_{3}$ and $\mathrm{X}_{4}$ were coded variables that represents $\mathrm{B}, \mathrm{C}$ and $\mathrm{D}$ and the $\beta$ 's were regression coefficient that obtained from the effects estimate as we did previously. Therefore, the prediction equation was for Saccharomyces cerevisiae $\mathrm{CS}$,

$$
\mathrm{Y}=0.2262+(0.053 / 2) \cdot \mathrm{X}_{2}+(0.063 / 2) \cdot \mathrm{X}_{4}+(0.073 / 2) \cdot \mathrm{X}_{1} \mathrm{X}_{2}+(0.053 / 2) \cdot \mathrm{X}_{1} \mathrm{X}_{3}
$$

And for Saccharomyces cerevisiae MS,

$$
Y=0.1475+(0.070 / 2) \cdot X_{2}+(0.030 / 2) \cdot X_{4}+(0.045 / 2) \cdot X_{1} X_{3}
$$

Remembering that the intercept $\beta_{0}$ is the average of all responses at the eight trials in the design ${ }^{[13]}$.

The model was presented with the geometric presentation and resented in Figure 2 and Figure 3. The geometric presentation helped us to identify the best condition for the maximum cell production. According to Figure 2, the best biomass production of $S$. cerevisiae $(\mathrm{CS})\left(0.39 \mathrm{~g} . \mathrm{L}^{-1}\right)$ was obtained using $1 \%$ potato powder concentration, orbital agitation at $150 \mathrm{rpm}$ for $25 \mathrm{hrs}$. According to the Figure 3, the best biomass production of S. cerevisiae (MS) (0.23 g.L $\left.{ }^{-1}\right)$ was obtained using $1 \%$ potato powder concentration, orbital agitation at $150 \mathrm{rpm}$ for $25 \mathrm{hrs}$.

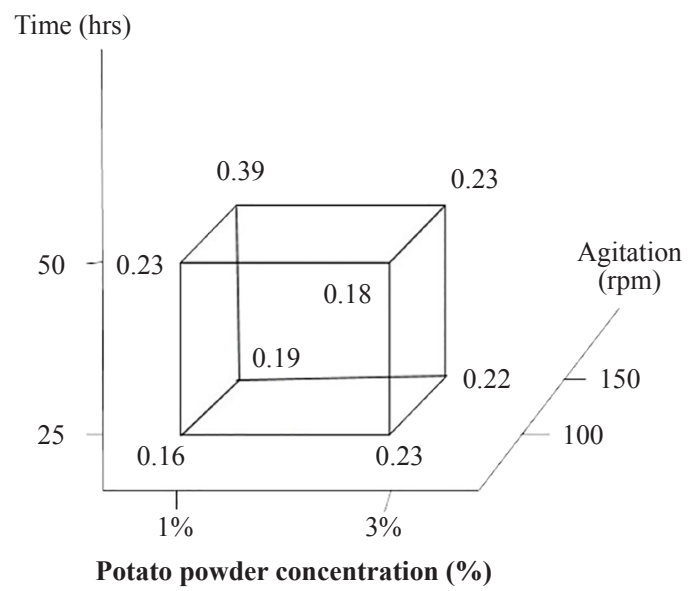

Figure 2. Geometrical representation of the results from the $2^{4-1}$ design of biomass production of S. cerevisiae (CS) 


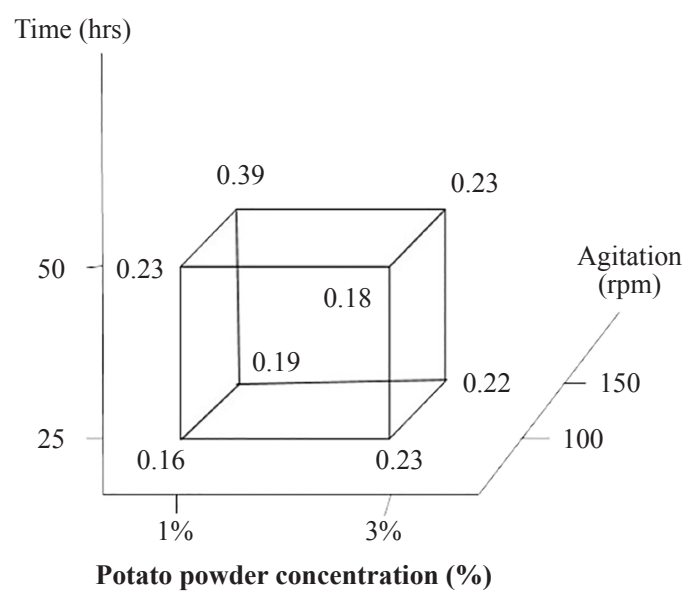

Figure 3. Geometrical representation of the results from the $2^{4-1}$ design of biomass production of S. cerevisiae (MS)

\section{Conclusion}

The study concludes that both strains' biomass yield and ethanol production were significantly affected by potato flour as a substrate. Four factors of biomass production were analyzed and large effects estimated for developing a model to determine the most suitable condition (at $1 \%$ of potato powder concentration, temperature at $30^{\circ} \mathrm{C}$ and agitation at 150 $\mathrm{rpm}$ ) for yeast growth on potato flour. Four variables with the two-level fractional factorial design were used to determine the effects of potato powder concentration, time, temperature, agitation on biomass and ethanol production from two types of yeast strains. The predictive model was developed to describe the relationship between the response and the variables. It allowed the identification of statistically significant variables and the quantitative evaluation of the effect of each variable on biomass production and the interactions between two variables.

\section{Acknowledgement}

The authors express heartfelt gratitude and also humbly desire to acknowledge heartiest appreciation to the Ministry of NSICT (National Science and Information and Communication Technology) for awarding a scholarship and the Bangladesh Agricultural Research System (BAURES) for providing research grants to conduct the study.

\section{Conflict of interests}

The authors declare no conflicts of interest.

\section{References}

[1] Prasertwasu S, Khumsupan D, Komolwanich T, Chaisuwan T, Luengnaruemitchai A, Wongkasemjit S. Efficient process for ethanol production from Thai Mission grass (Pennisetumpolystachion). Bioresource Technology. 2014; 163: $152-159$.

[2] Jorgensen H, Olsson L, Ronnow B, Palmqvist EA. Fed-batch cultivation of Bakers yeast followed by nitrogen or carbon starvation: Effects on fermentative capacity and content of trehalose and glycogen. Applied Microbiol. Biotechnol. 2002; 59: 310-317.

[3] Bekatorou A, Psarianos C, Koutinas AA. Production of food grade yeasts. Food Technology and Biotechnology. 2006; 44: 407-415.

[4] Fernandez-Lopez CL, Torrestiana-Sanchez B, Salgado-Cervantes MA, Mendoza Garcia PG, Aguilar-Uscanga MG. Use of sugarcane molasses "B" as an alternative for ethanol production with wild-type yeast Saccharomyces cerevisiae ITV-01 at high sugar concentrations. Bioprocess and Biosystems Engineering. 2012; 35(4): 605-614.

[5] Kasavi C, Finore I, Lama L. Evaluation of industrial Saccharomyces cerevisiae strains for ethanol production from biomass. Biomass \& Bioenergy. 2012; 45: 230-238.

[6] Balat M, Balat H, Oz C. Progress in bioethanol processing. Progress in Energy and Combussion Science. 2008; 34 : 551-573.

[7] Akaracharanya A, Kesornsit J, Leepipatpiboon N, Srinorakutara T, Kitpreechavanich V, Tolieng V. Evaluation of the waste from cassava starch production as a substrate for ethanol fermentation by Saccharomyces cerevisiae. Annals of 
Microbiology. 2011; 61(3): 431-436.

[8] Le Man H, Rene ER, Behera SK, Park HS. Main and interaction effects of process parameters on the ethanol production capacity of food-waste leachate by SaccharomycesCerevisiae. KSCE Journal of Civil Engineering. 2011; 15(6): 1015-1022.

[9] Li F, Guan LL. Metatranscriptomic profiling reveals linkages between the active rumen microbiome and feed efficiency in beef cattle. Appl Environ Microbiol. 2017; 83(9): e00061-17.

[10] Nalley L, Hudson D. The potential viability of biomass ethanol as a renewable fuel sourece: A discussion. In Starkville. (ed.) MS: Mississippi State University-Staff Report. Report number: 003, 2003.

[11] Park JM, Oh BR, Seo JW. Efficient production of ethanol fromempty palm fruit bunch fibers by fed-batch simultaneous saccharification and fermentation using Saccharomycescerevisiae. Applied Biochemistry and Biotechnology. 2013; 170(8): 1807-1814.

[12] Jahan N, Azmuda N, Khan AR. Isolation and Identification of Indigenous Baker's Yeast. Bangladesh Journal of Microbiology. 2007; 24(1): 65-66.

[13] Melo IR, Pimentel MF, Lopes CE, Calazans GMT. Application of fractional factorial design to levan production by Zymomonas mobilis. Brazilian Journal of Microbiology. 2007; 38: 45-51.

[14] Hashem M, Darwish SMI. Production of bioethanol and associated by products from potato starch residue stream by Saccharomyces cerevisiae. Journal of Biomass and Bioenergy. 2010; 34: 953-959.

[15] AOAC: Determination of Moisture, Ash, Protein and Fat. Official Methods of Analysis. 8th ed. Washington, D.C.; 2005 .

[16] AOAC: Official Methods of Analysis. Association of Official Analytical Chemists. 12th ed. Washington, D.C., USA.; 2015.

[17] Briggs DE, Boulton CA. Brewing Science and Practice. P. A. Brooks, R. Stevens Woodhead Publishing Limited and CRC Press LLC; 2004.

[18] Friedman N. Spectrophotometer, OD, and yeast growth. The Friedman Lab Chronicles; 2010.

[19] Reiss M, Hartmeier W. Levan production with a flocculent strain of Zymomonas mobilis. Food Biotechnology. 1990; 4(1): 69-75.

[20] Montreka YD, Adelia CBB. Production and proximate composition of a hydroponic sweet potato flour during extended storage. Journal of Food Processing and Preservation. 2007; 27(2): 153-164.

[21] Kaur A, Kochhar A, Prasad P. Development and nutritional evaluation of products using potato flour for malnourished children. International Journal of Health Sciences and Research. 2015; 5(6): 554-560.

[22] Boni VWT, Digbeu YD, Dje MK, Kouame LP, Due EA. Proximate and mineral composition and some anti-nutritional factors of flour from five improved sweet potato (Ipomoea batatas (1.) Lam) varieties roots. European journal of pharmaceutical and medical research. 2018; 5(11): 126-137.

[23] Rath S, Singh AK, Masih H, Kumar Y, Peter JK, Singh P, Mishoura SK. Bioethanol production from waste potatoes as an environmental waste management and sustainable energy by using cocultures Aspergillus niger and Saccharomyces cerevisiae. International Journal of Advanced Research. 2014; 2(4): 553-563.

[24] Ivanova V, Yankov D, Kabavanova D, Pashkoulov D. Simultaneous biosynthesis and purification of two extracellular Bacillus hydrolases in aqueous two alpha amylase. Journal of Biochemistry. 2001; 8: 61-81.

[25] Liimatainen H, Kuokkanen T, Kaariainen J. Development of bio-ethanol production from waste potatoes. In: Pongracz E. (ed.) Proceedings of the Waste Minimization andResources Use Optimization Conference, University of Oulu, Finland. Oulu University Publishing; 2004. p.123-129.

[26] Magdy M, Afifi Abd El-Ghany TM, Mohamed A, Al Abboud, Taher MT, Khaled E, Ghaleb. Biorefinery of Industrial Potato Wastes to ethanol by Solid State Fermentation. Research Journal of Agriculture and Biological Sciences. 2011; 7(1): 126-134.

[27] Montgomery DC. Design and analysis of experiments. 5th ed. New York: John Wiley and Sons; 2001. p.684. 